\title{
Growth dynamics and allometric relationships of Passiflora species rootstocks
}

\author{
Marcos Antônio Dell'Orto Morgado', Claudio Horst Bruckner², \\ Luciana Domiciano Silva Rosado², Carlos Eduardo Magalhães dos Santos²* \\ 'Espirito Santo Federal Institute of Education, Science and Technology, Colatina, ES, Brazil \\ ${ }^{2}$ Federal University of Viçosa, Viçosa, MG, Brazil \\ *Corresponding author, e-mail: carlos.magalhaes@ufv.br
}

\begin{abstract}
Passion fruit (Passiflora edulis Sims) is characterized by being a tropical fruit, with significant production in Brazil, however the occurrence of diseases, especially fungal infections that affects the root system, has reduced its production. Some Passifloraceae species are reported as being resistant to these pathogens, which feature in potential rootstock for $P$. edulis cultivation in contaminated areas, although the patterns of growth and development of these species has not being elucidated yet. Thus, the objective was to study the dynamics of growth and evaluate the dry matter distribution of passion fruit with potential rootstock use. Passiflora cincinnata, Passiflora mucronata, Passiflora giberti, Passiflora morifolia and Passiflora edulis (control) developed in polyvinyl chloride tubes of $100 \mathrm{~mm}$ in diameter and $150 \mathrm{~cm}$ in height, in order to assess plant height, leaf area, number of secondary roots, stem diameter, taproot lenght, root system volume, absolute growth rate, relative growth rate, net assimilation rate, leaf mass ratio and root mass ratio, at 30, 45, 60, 75, 90 and 105 days after transplanting. The species $P$. cincinnata, $P$. giberti and $P$. morifolia presented higher or similar growth rates than $P$. edulis for all evaluated characteristics, throughout the evaluation period. The root system of the species $P$. giberti and $P$. morifolia showed better distribution along the substrate. The species $P$. mucronata obtained lower growth than other species, both for the shoot and the root system.
\end{abstract}

Keywords: graft compatibility, growth rate, passifloraceae

\section{Dinâmica de crescimento e relações alométricas de espécies de Passiflora potencialmente uteis como porta-enxertos}

\section{Resumo}

O maracujazeiro azedo (Passiflora edulis Sims) caracteriza-se por ser uma fruteira tropical, com expressiva produção no Brasil, entretanto a ocorrência de doenças fúngicas associadas ao sistema radicular tem proporcionado redução na produção. Algumas espécies da família Passifloraceae são relatadas como resistentes a estes fitopatógenos, caracterizando em potenciais porta-enxerto para cultivo do $P$. edulis. Deste modo, objetivou-se estudar a dinâmica de crescimento e distribuição de massa seca de passifloráceas com potencial de uso como porta-enxerto do maracujazeiro azedo. As espécies Passiflora cincinnata, Passiflora mucronata , Passiflora giberti, Passiflora morifolia e Passiflora edulis (controle); foram colocadas para desenvolver em tubos de PVC de $100 \mathrm{~mm}$ de diâmetro e 150 centímetros de altura, avaliando a altura da planta, área foliar, número de raízes secundárias, diâmetro do caule, comprimento da raiz pivotante, volume do sistema radicular, taxa de crescimento absoluto, taxa de crescimento relativo, taxa assimilatória líquida, razão de peso foliar e razão de peso radicular; aos 30, 45, 60, 75, 90 e 105 dias após o transplantio. As espécies P. cincinnata, P. giberti e P. morifolia apresentaram taxas de crescimento iguais ou superiores ao $P$. edulis em todas as características avaliadas, durante todo período de avaliação. O sistema radicular das espécies $P$. giberti e $P$. morifolia apresentaram melhor distribuição ao longo do substrato. A espécie P. mucronata obteve crescimento inferior às demais espécies, tanto da parte aérea quanto do sistema radicular.

Palavras chave: compatibilidade do enxerto, passifloraceae, taxa de crescimento

$\begin{array}{llll}\text { Received: } & 22 & \text { July } & 2015 \\ \text { Accepted: } & 13 & \text { May } & 2016\end{array}$




\section{Introduction}

Passion fruit (Passiflora edulis Sims) is characterized by being a tropical fruit, with significant production in Brazil, however the occurrence of diseases, especially fungus that affects the root system, has resulted in a reduction in the crop production and area of cultivation in certain regions of the country.

Among these diseases, fusarium wilt is the main one, caused by the fungus Fusarium oxysporum f. sp. passiflorae (Fischer \& Resende, 2008; Bueno et al., 2009). The disease is initially characterized by a yellowing and wilting of the branches, progressing to a dryness of the plant due to the rot that affects the stem and the root system (Fischer et al., 2005), resulting in shorter life of the orchards (Silva et al., 2005b).

As an alternative to controlling soil pathogens, the use of resistant cultivars is the farms's preferred method, due to the benefits of low cost and ease of implementation. However, cultivated varieties of passion fruit are susceptible to fusarium wilt (Roncatto et al., 2004; Fischer et al., 2005; Fischer et al., 2010).

The species $P$. alata, $P$. giberti, $P$. quadrangularis, P. macrocarpa, P. caerulia and $P$. nitida, which have been reported to be resistant to Fusarium oxysporum f. sp. passiflorae, may be used as rootstocks (Fischer et al., 2005; Silva et al., 2013). However, the growth patterns of these passion fruit species in the different producing regions are often reported regarding the production point of view, without paying proper attention to anatomical, morphological and physiological traits (Vasconcellos et al., 2005).

Fageria \& Stone (2006) and Fageria \& Moreira (2011) emphasize that the rooting pattern is under genetic control, but the root growth can be modified by chemical and physical traits of the soil. Thus, Passiflora species with the greatest development of the root system allow the exploration of a greater soil volume, enabling higher water and nutrients absorption by plants, especially during drought periods.

Knowledge of the plant growth and development pattern of wild species can lead to information about the different growth stages and plant growth patterns, allowing analysis of the root system behavior of these species, such as the important parameters that could affect rootstock choice. Vasconcellos et al. (2005) state that ecophysiological studies of passion fruit (phenophases and plant physiology) are scarce, leading to a more defined understanding of the phenomena related to plant growth and development.

Thus, the objective of this study was to understand the dynamics of growth and dry matter distribution of passion fruit species with potential use for rootstock.

\section{Material and Methods}

The experiment was conducted from October 2010 to March 2011 in the experimental area of the Department of Plant Science at the Federal University of Viçosa (UFV), Viçosa / MG. Geographically, the experimental area is located at a latitude of $20^{\circ} 45^{\prime}$ South and longitude of $42^{\circ} 52^{\prime}$ West, with an altitude of about $650 \mathrm{~m}$ and an average annual temperature of $19^{\circ} \mathrm{C}$.

The species studied were obtained from the passion fruit wild collection belonging to the institution, and comprised the following species: Passiflora cincinnata Mast, Passiflora mucronata Lam, Passiflora giberti NE Br, Passiflora morifolia Mast. and Passiflora edulis Sims (control).

Seeds of the different species were extracted from the fruits, stored in the refrigerator, and subsequently germinated, without treatments for dormancy breaking or fungal diseases control, in plastic boxes with washed sand and with $40 \times 20 \times 100 \mathrm{~cm}$ (width $\times$ height $x$ length). After complete the cotyledonary leaves expansion, over a period of 15 to 45 days, depending on the species, 48 seedlings of each species were transplanted to polyvinyl chloride (PVC) tubes measuring $100 \mathrm{~mm}$ in diameter and $150 \mathrm{~cm}$ in height, containing a mixture of soil corrected for acidity and fertilized, sand and manure in a proportion of 3:1:1 (v:v:v) with the following chemical traits: $P=449.00 ; K=260,00$; (all in $\mathrm{cmolc} \mathrm{dm}^{-3}-$ Mehlich extractor); $\mathrm{Ca}^{+2}=$ 6.87; $\mathrm{Mg}^{+2}=1.62 ; \mathrm{Al}^{+3}=0.00$; (all cmolc. $\mathrm{dm}^{-3}-\mathrm{KCl}$ extractor); $\mathrm{pH}\left(\mathrm{H}_{2} \mathrm{O}\right)=5.96 ; \mathrm{H}+\mathrm{Al}=4.20$ (cmolc. $\mathrm{dm}^{-3}$ - Calcium Acetate extractor); $\mathrm{SB}=15,16 ; \dagger=$ 15,$16 ; \mathrm{T}=19.36$; (all cmolc. $\left.\mathrm{dm}^{3}{ }^{3}\right) ; \mathrm{V}=78.30 \% ; \mathrm{m}$ $=0.0 \%$. 
The seedlings taproots was sectioned at $5 \mathrm{~cm}$ from the seedlings stem, avoiding the occurrence of roots folding during transplanting. The tubes were arranged in 15 rows and spaced with $50 \mathrm{~cm}$.

The root and shoot growth variables were determined in eight plants of each species, the first being evaluated after transplanting and the others at 30,45, 60, 75, 90 and 105 days after transplanting (DAT). For each evaluation, the plants were sampled by the destructive method, removing the soil of the root system by washing under running water, and getting to the end of the operation with intact plant roots. The following traits were determined: plant height, measured from the stem to the apex; leaf number; leaf area, measured using a LI-3100C Leaf Area Meter; number of secondary roots, by direct counting of roots formed from the taproot length at $10 \mathrm{~cm}$ depth intervals; stem diameter, measured at $5 \mathrm{~cm}$ above the stem; taproot length, measured from the stem to the root end and root system volume by displacement of the water volume.

After these determinations, the material was packed separately (stem, leaves and roots) in paper bags and dried at $65^{\circ} \mathrm{C}$ in an oven with forced air circulation until constant weight to evaluate the dry matter.

From the leaf area (LA) and dry matter the following physiological parameters were calculated: a) absolute growth rate (AGR), determined by the derivative of the equation of the mass of the total dry matter in relation to time, expressed in g.day $^{-1}$; b) relative growth rate, expressed in $9 . \mathrm{g}^{-1} \cdot \mathrm{day}^{-1}$ and calculated by the quotient between the absolute growth rate and the mass of the total dry matter; c) net assimilation rate (NAR), calculated using the formula cited by Benincasa (2003): NAR = $A G R^{*}\left(\left(\ln \left(\operatorname{LA}_{n}\right)-\left(\ln \left(\operatorname{LA}_{n-1}\right)\right)-\left(\operatorname{LA}_{n}-\operatorname{LA}_{n-1}\right)\right)\right.$, in g.dm ${ }^{-2}$. $\mathrm{dia}^{-1}$; d) leaf mass ratio, defined as the ratio of the mass of the dry matter of the leaf to the mass of the total dry matter; e) root mass ratio, defined as the ratio of the mass of the dry matter of roots (DMR) to total dry matter.

The data were submitted to variance and regression analysis. In regression analysis, linear and quadratic effects were tested, selecting the equation with significantly effect the $\mathrm{F}$ test at $5 \%$ probability and higher coefficient of determination $\left(R^{2}\right)$ was observed. The plant age was considered the independent variable, expressed in days after transplanting. To study the growth variables and allometric relationships, 30 -day of intervals were used. The species were compared by Tukey's test at a $5 \%$ of significance level. The statistical the analysis were carried out using the SAS statistical software (SAS Institute, 2010).

\section{Results and Discussion}

In order to study the growth of potentially useful passiflora species with $P$. edulis rootstocks, regression equations were estimated using biweekly data (Tables 1 and 2), describing growth and dry matter accumulation with high precision, with determination of coefficients higher than 0.94 (Table 1).

The plants growth analysis enables the quantification of the contribution of different physiological processes for plant growth, and is applicable to the study of variations among genetically different plants or when submitted to different environmental conditions, providing the knowledge of plant biomass production kinetics and distribution and efficiency throughout ontogeny (Aguilera et al., 2004; Carvalho et al., 2008). Thus, the estimated growing by regression equations of wild passiflora and $P$. edulis (Table 2) enable the estimation, based on stem diameter, of the number of days needed between sowing and the grafting process, due to the slow growth of wild passiflora, allowing a compatible diameter at the time of grafting.

The absolute growth rate is the difference in biomass in the considered period of time and provides an estimate of the average growth rate of the plant during the development cycle (Benincasa, 2003; Aguilera et al., 2004), beyond the identification of characters that allows the establishment of a relation between the initial growth and yield increase at the reproductive phase, favoring the application of the selection stage in breeding programs during the initial growth phase (Lima et al., 2007).

At 30 days after transplanting (DAT), P. mucronata showed an absolute growth rate 
Table 1. Regression equations between leaves dry matter, stem dry matter, roots dry matter and total dry matter with age $(X)$, expressed in days after transplanting ( 15 to 105 days)

\begin{tabular}{|c|c|c|c|c|c|}
\hline \multirow{2}{*}{ Variables } & \multirow{2}{*}{ Species } & \multicolumn{3}{|c|}{ Parameter $^{1}$} & \multirow{2}{*}{$\mathrm{R}^{2}$} \\
\hline & & $a$ & $b$ & C & \\
\hline \multirow{5}{*}{$\begin{array}{c}\text { Leaves dry } \\
\text { matter }\end{array}$} & P. cincinnata & -1.3934 & 1.236 & - & 0.98 \\
\hline & P. edulis & -0.171 & 0.2027 & 0.106 & 0.99 \\
\hline & P. giberti & -0.1879 & 0.1449 & 0.1476 & 0.98 \\
\hline & P. morifolia & -1.3694 & 1.2805 & - & 0.97 \\
\hline & P. mucronata & 0.5987 & -0.7149 & 0.2024 & 0.99 \\
\hline \multirow{5}{*}{$\begin{array}{c}\text { Stem dry } \\
\text { matter }\end{array}$} & P. cincinnata & -0.8976 & 0.0331 & 0.0006 & 0.98 \\
\hline & P. edulis & -0.3471 & 0.0387 & 0.0011 & 0.98 \\
\hline & P. giberti & 0.6414 & -0.0807 & 0.0025 & 0.97 \\
\hline & P. morifolia & -0.1245 & -0.0093 & 0.0008 & 0.99 \\
\hline & P. mucronata & 0.2326 & -0.0221 & 0.0005 & 0.98 \\
\hline \multirow{5}{*}{$\begin{array}{c}\text { Roots dry } \\
\text { matter }\end{array}$} & P. cincinnata & -0.0704 & -0.0159 & 0.0011 & 0.98 \\
\hline & P. edulis & -0.2777 & 0.0012 & 0.0007 & 0.97 \\
\hline & P. giberti & -0.4492 & 0.0077 & 0.0008 & 0.98 \\
\hline & P. morifolia & -0.4786 & 0.0033 & 0.0012 & 0.99 \\
\hline & P. mucronata & 0.6998 & -0.0561 & 0.0001 & 0.97 \\
\hline \multirow{5}{*}{$\begin{array}{c}\text { Total dry } \\
\text { matter }\end{array}$} & P. cincinnata & -1.872 & $0 . .752$ & 0.002 & 0.99 \\
\hline & P. edulis & -0.1016 & -0.024 & 0.0022 & 0.99 \\
\hline & P. giberti & 0.0672 & -0.0634 & 0.0039 & 0.99 \\
\hline & P. morifolia & -1.8215 & 0.0717 & 0.0021 & 0.98 \\
\hline & P. mucronata & 1.531 & -0.1258 & 0.0024 & 0.98 \\
\hline
\end{tabular}

Table 2. Regression equations between leaf area, leaf number, plant height, stem diameter, root system volume and length of the taproot with age (X), expressed in days after transplanting (15 to 105 days)

\begin{tabular}{|c|c|c|c|c|c|}
\hline \multirow{2}{*}{ Variables } & \multirow{2}{*}{ Species } & \multicolumn{3}{|c|}{ Parament $^{1}$} & \multirow{2}{*}{$\mathrm{R}^{2}$} \\
\hline & & $a$ & $b$ & C & \\
\hline \multirow{5}{*}{$\begin{array}{l}\text { Leaf } \\
\text { area }\end{array}$} & P. cincinnata & -16061 & 968.23 & 4.1082 & 0.98 \\
\hline & P. edulis & -10577 & 632.64 & 4.1787 & 0.98 \\
\hline & P. giberti & -22819 & 1316.4 & - & 0.97 \\
\hline & P. morifolia & -21284 & 1273.9 & 8.1857 & 0.99 \\
\hline & P. mucronata & 5452.3 & -465.37 & 10.636 & 0.98 \\
\hline \multirow{5}{*}{$\begin{array}{l}\text { Leaf } \\
\text { number }\end{array}$} & P. cincinnata & 2.7305 & 0.1466 & 0.0014 & 0.99 \\
\hline & P. edulis & 3.4857 & 0.0256 & 0.0015 & 0.96 \\
\hline & P. giberti & 6.3732 & -0.0131 & 0.0049 & 0.98 \\
\hline & P. morifolia & 0.0773 & 0.3127 & 0.0015 & 0.97 \\
\hline & P. mucronata & 2.2838 & 0.0731 & 0.0020 & 0.95 \\
\hline \multirow{5}{*}{$\begin{array}{l}\text { Plant } \\
\text { height }\end{array}$} & P. cincinnata & -25.621 & 1.4278 & 0.0091 & 0.98 \\
\hline & P. edulis & -13.291 & 0.5573 & 0.0141 & 0.98 \\
\hline & P. giberti & -19.188 & 0.9696 & 0.0241 & 0.99 \\
\hline & P. morifolia & -45.519 & 2.4293 & 0.0088 & 0.97 \\
\hline & P. mucronata & 3.0513 & -0.1188 & 0.0082 & 0.95 \\
\hline \multirow{5}{*}{$\begin{array}{l}\text { Stem } \\
\text { diameter }\end{array}$} & P. cincinnata & 1.8324 & 0.0471 & - & 0.96 \\
\hline & P. edulis & 1.6373 & 0.0511 & - & 0.98 \\
\hline & P. giberti & 1.6100 & 0.0564 & - & 0.96 \\
\hline & P. morifolia & 0.5352 & 0.1574 & -0.0011 & 0.98 \\
\hline & P. mucronata & 1.5394 & 0.0043 & 0.0003 & 0.98 \\
\hline \multirow{5}{*}{$\begin{array}{l}\text { Root } \\
\text { system } \\
\text { volume }\end{array}$} & P. cincinnata & 0.9355 & -0.1431 & 0.0096 & 0.99 \\
\hline & P. edulis & -0.7368 & -0.1089 & 0.0086 & 0.99 \\
\hline & P. giberti & 3.339 & -0.1936 & 0.0100 & 0.99 \\
\hline & P. morifolia & -1.3945 & -0.1172 & 0.0162 & 0.97 \\
\hline & P. mucronata & 6.3432 & -0.4759 & 0.0088 & 0.96 \\
\hline \multirow{5}{*}{$\begin{array}{l}\text { Length of } \\
\text { taproof }\end{array}$} & P. cincinnata & 11.3420 & 1.5075 & - & 0.99 \\
\hline & P. edulis & 1.0500 & 1.7300 & - & 0.99 \\
\hline & P. giberti & 7.5083 & 1.5486 & - & 0.94 \\
\hline & P. morifolia & 13.1920 & 1.3973 & - & 0.98 \\
\hline & P. mucronata & 7.3517 & 0.9823 & - & 0.97 \\
\hline
\end{tabular}

Com. Sci., Bom Jesus, v.8, n.1, p.1-8, Jan./Mar. 2017 
significantly lower than other species, whith no difference among them (Figure 1). At 60 DAT, P. morifolia presented higher absolute growth rate than $P$. edulis, and $P$. mucronata presented again the lowest rate. Already at 90 DAT, $P$. morifolia was superior than P. mucronata, and did not differ from the others.

According to Benincasa (2003), the absolute growth rate can be used to estimate the average growth speed over the evaluation
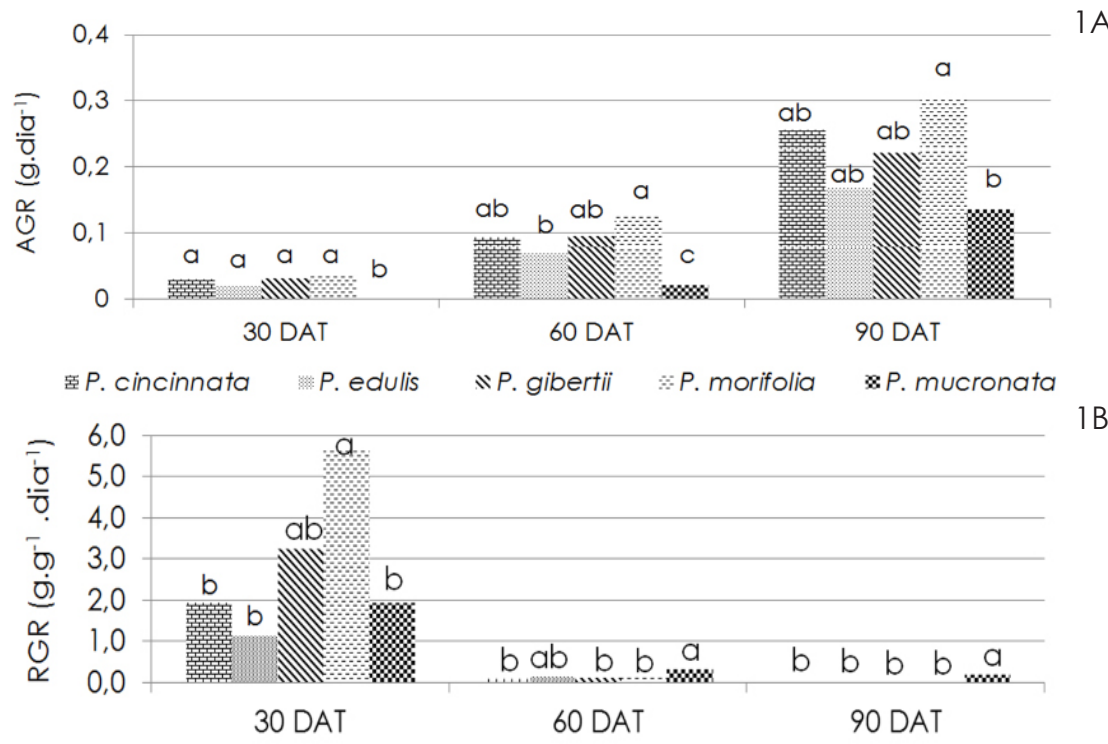

䔄P. cincinnata $P$. edulis $N$. gibertii $P$. morifolia $\otimes P$. mucronata

Figure 1. Absolute growth rate (AGR) and relative growth rate (RGR) of P. cincinnata, $P$. edulis, P. giberti, P. morifolia e P. mucronata at 30, 60 e 90 days after transplanting. Means followed by the same letters in each evaluation time do not differ according to Tukey's test $(p<0.05)$.

period, thus species with the lowest value, in this case $P$. mucronata, may be the result of slow growth in the initial stages but a long-lived life cycle (Meletti et al., 2011).

The net assimilation rate discloses the biomass production efficiency, i.e. the amount of biomass formed per unit time in relation to the leaf area which contributed to the formation of that biomass, during the considered time interval. The species did not differ by $\mathrm{F}$ test at $5 \%$ probability.

The relative growth rate is the amount of plant material produced by a certain amount of material (g) during a prefixed time interval (days) (Silva et al., 2005a). The relative growth rate presented at 30 DAT by $P$. morifolia was significantly higher than the other species, with the exception of $P$. giberti, which did not differ significantly from any species (Figure 1). Different behavior was observed at 60 DAT, when $P$. mucronata showed the highest values and did not differed statistically from $P$. edulis. The superiority of $P$. mucronata remained until 90 DAT.

In general, the highest values for relative growth rate were observed at the first assessment
(30 DAT), with a decrease in the following evaluations. These decreases in the relative growth rate over time may be due to continuous accumulation of dry matter in the course of time, and by decreasing the relative ability of the plant to produce new material, as observed by Barreiro et al. (2006) in plants of Ocimum basilicum L. treated with plant growth regulators and Antoniazzi \& Deschamps (2006) in barley plants treated with elicitors and fungicides.

The reduction of the relative growth rate in all species, from 60 DAT, may be due to the increased proportion of non-photosynthetic tissues compared to photosynthetic tissues, which results in decreased availability of assimilates to withstand high relative growth rates (Ferrari et al., 2008; Mesquita et al., 2012). The increase in the mass of non-photosynthetic tissues can be seen when observing the increase in root mass ratio (Figure 2) and a consequent reduction in leaf mass ratio (Figure 2) from 60 DAT for all species.

Lima et al. (2006) studied the germination and early growth of Passiflora edulis sims $f$. flavicarpa Deg., Passiflora edulis f. edulis Sims, 
Passiflora giberti N.E. Br. and Passiflora laurifolia L. and Passiflora alata Curtis, and found that higher plant height and shoot dry matter were presented by $P$. giberti.

As for the root system, $P$. mucronata had a shorter root length than other species, with no significant differences. The dry matter of the root system of $P$. mucronata was less than other species dry matter at 15 DAT and 45 DAT. At DAT it was lower than P. morifolia (Figure 3).

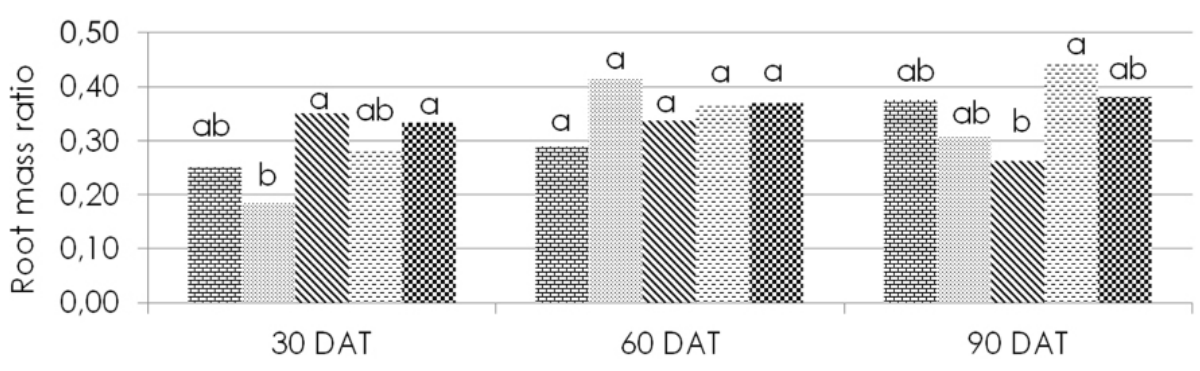

呏 $P$. cincinnata $P$. edulis NP. gibertii $* P$. morifolia $\approx P$. mucronata

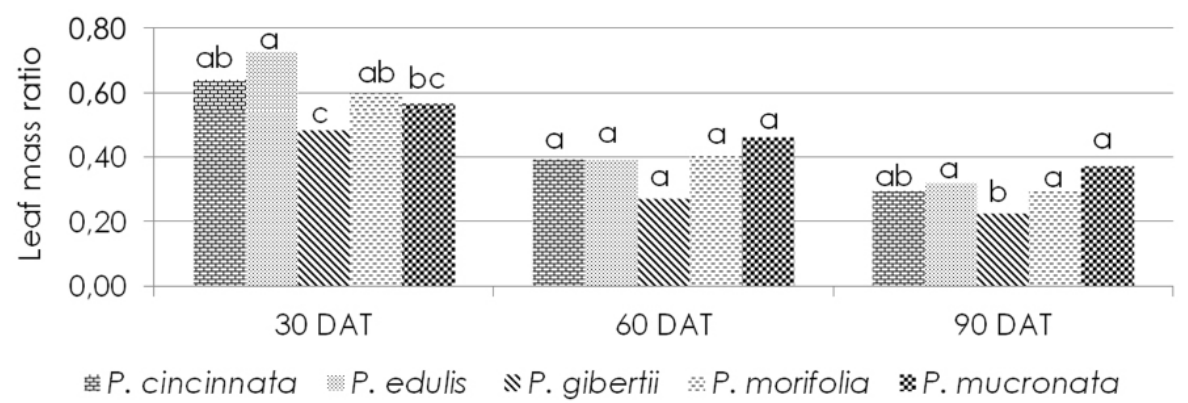

Figure 2. Root mass ratio and leaf mass ratio of $P$. cincinnata, $P$. edulis, $P$. giberti, P. morifolia and P. mucronata at 30,60 e 90 days after transplanting (DAT). Means followed by the same letters in each evaluation time, do not differ according to Tukey's test $(p<0.05)$.

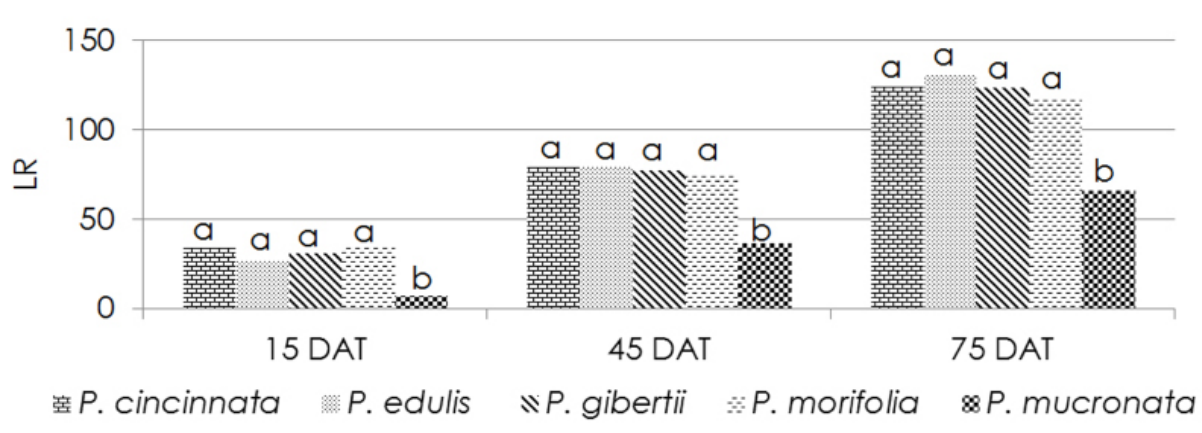

$3 \mathrm{~A}$

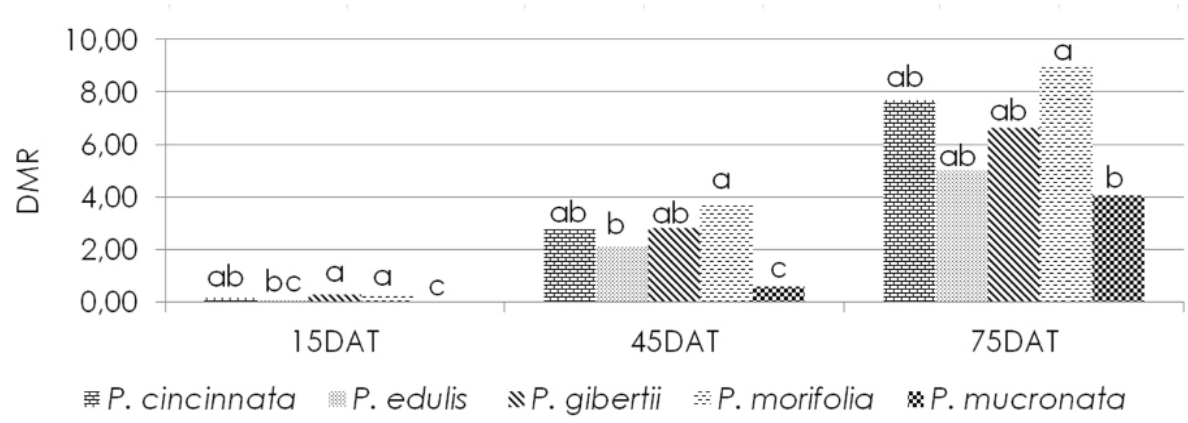

Figure 3. Taproot length (LR) and root dry matter (DMR), in grams, of $P$. cincinnata, $P$. edulis, $P$. giberti, $P$. morifolia and P. mucronata at 15, 45 and 75 days after transplanting (DAT). Means followed by the same letters in each evaluation time, are not different according to Tukey's test $(p<0.05)$. 
The number of secondary roots of $P$. giberti at 75 DAT was significantly higher for all evaluated depths, with the exception of $0-10$ $\mathrm{cm}$ and $40-50 \mathrm{~cm}$ (Figure 4). P. giberti in the early development features a thin stem, a delicate green color and rapid vegetative growth: however, when adult it presents as vigorous (Aguiar et al. 2010).

Plant growth analysis can be used as an important technique for the evaluation of plant adaptations to various cultivation conditions (Ludwig et al. 2010), allowing the selection of Passiflora species adapted to specific growing conditions.
Thus, the wider distribution of the root system of $P$. giberti and $P$. morifolia in relation to other species suggests better exploitation of the soil in volume and depth. These characteristics may improve tolerance to drought, since in periods of water stress in the soil there is usually greater availability of water at deeper levels, enabling a better supply of water and minerals to the plants.

The results allowed the research to support the use of resistant rootstock major diseases and soil pests of passion fruit, and demonstrate the development of species in order to adequately protect passion fruit seedling rootstock.

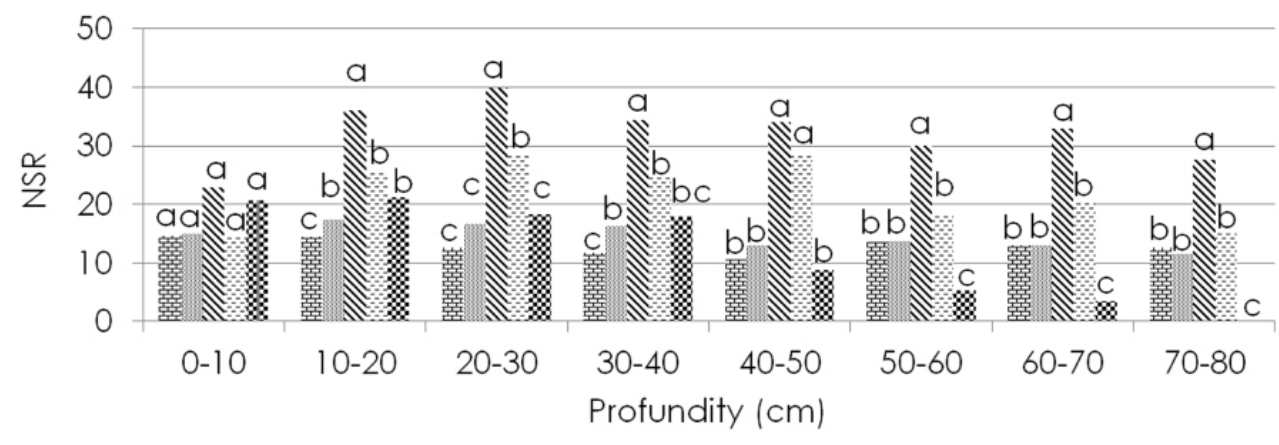

号P. cincinnata $P$. edulis NP. gibertii : $P$. morifolia $\approx$. mucronata

Figure 4. Number of secondary roots (NSR) of $P$. cincinnata, $P$. edulis, $P$. giberti, $P$. morifolia and $P$. mucronata to 75 days after transplanting (DAT), at $10 \mathrm{~cm}$ depth intervals. Means followed by the same letters in each evaluation time, do not differ according to Tukey's test $(p<0.05)$.

\section{Conclusions}

1. P. cincinnata, P. giberti and P. morifolia presented higher or similar growth rates than $P$. edulis for all variables throughout the evaluation period:

2. The P. giberti and $P$. morifolia root systems presented better distribution along the substrate. P. mucronata obtaining lower growth than other species, both in shoot and the root system.

\section{References}

Aguiar, A.V.M., Silva, R.M., Cardoso, E.A., Maracajá, P.B., Pires, H.G. 2010. Utilização de espécies de passiflora spp. como porta-enxertos no controle de doenças do maracujazeiro. Agropecuária Científica no Semi-Árido 06: 17-22.

Aguilera, D.B., Ferreira, F.A., Cecon, P.R. 2004. Crescimento de Siegesbeckia orientalis sob diferentes condições de luminosidade. Planta Daninha 22: 43-51.
Antoniazzi, N., Deschamps, C. 2006. Análise de crescimento de duas cultivares de cevada após tratamentos com elicitores e fungicidas. Ciência Rural 36: 1065-1071

Barreiro, A.P., Zucareli, V., Ono, E.O., Rodrigues, J.D. 2006. Análise de crescimento de plantas de manjericão tratadas com reguladores vegetais. Bragantia 65: 563-567.

Benincasa, M.M.P. 2003. Análise de crescimento de plantas: noções básicas. FUNEP, Jaboticabal, Brasil. 41p.

Bueno, C.J., Fischer, I.H., Rosa, D.D., Furtado, E.L. 2009. Produção de enzimas extracelulares por Fusarium solani de maracujazeiro amarelo. Tropical Plant Pathology 34: 343-346.

Carvalho, S.J.P., López-Ovejero, R.F., Christoffoleti, P.J. 2008. Crescimento e desenvolvimento de cinco espécies de plantas daninhas do gênero Amaranthus. Bragantia 67: 317-326.

Fageria, N.K., Stone, L.F. 2006. Physical, chemical, and biological changes in the rhizosphere and nutrient availability. Journal of Plant Nutrition 29: 
1327-1356.

Fageria, N.K, Moreira, A. 2011. The role of mineral nutrition on root growth of crop plants. Advances in Agronomy 110: 251-331.

Ferrari, T.B., Ferreira, G., Zucareli, V., Boaro, C.S.F. 2008. Efeito de reguladores vegetais nos índices da análise de crescimento de plântulas de maracujazeiro-doce (Passiflora alata Curtis). Biotemas 21: 45-51.

Fischer, I.H., Bueno, C.J., Garcia, M.J. de M., Almeida, A.M. de. 2010. Reação de maracujazeiro-amarelo ao complexo fusariosenematoide de galha. Acta Scientiarum 32: 223227.

Fischer, I.H., Lourenço, S.A., Martins, M.C., Kimati, H., Amorim, L. 2005. Seleção de plantas resistentes e de fungicidas para o controle da podridão do colo do maracujazeiro causada por Nectria hematococca. Fitopatologia Brasileira 30: $250-$ 258.

Fischer, I.H., Resende, J.A.M. 2008. Diseases of passion flower (Passiflora spp.). Pest Technology 2: 1-19.

Lima, A.A., Caldas, R.C., Santos, V.S. 2006. Germinação e crescimento de espécies de maracujá. Revista Brasileira de Fruticultura 28: 125-127.

Lima, J.F. de, Peixoto, C.P., Ledo, C.A. da S. 2007. Índices fisiológicos e crescimento inicial de mamoeiro (Carica papaya L.) em casa de vegetação. Ciência e Agrotecnologia 31:13581363.

Ludwig, F., Guerrero, A.C., Fernandes, D.M., Villas Boas, R.L. 2010. Análise de crescimento de gérbera de vaso conduzida em diferentes substratos. Horticultura Brasileira 28: 70-74.

Meletti, L.M.M., Soares-Scott, M.D., Bernacci, L.C., Alvares, V., Azevedo Filho, J.A. de. 2011. Caracterização de Passiflora mucronata Lam.: nova alternativa de maracujá ornamental. Revista Brasileira de Horticultura Ornamental 17: 87-95.

Mesquita, F. de O., Rebequi, A.M., Cavalcante, L.F., Souto, A.G. de L. 2012. Crescimento absoluto e relativo de mudas de maracujazeiro sob biofertilizante e águas salinas. Revista de Ciências Agrárias 35: 222-239.

Roncatto, G., Oliveira, J.C.R.C., Nogueira Filho, G.C., Centurion, M.A.P.C., Ferreira, F.R. 2004. Comportamento de maracujazeiros (Passiflora spp.) quanto à morte prematura. Revista Brasileira de Fruticultura 26: 552-554.

SAS Institute Inc. 2010. JMP, Version 9.0. Cary, NC:

\section{SAS Institute Inc.}

Silva, A. dos S., Oliveira, E.J. de, Haddad, F., Laranjeira, F.F., Jesus, O.N. de, Oliveira, S.A.S. de, Costa, M.A.P. de C., Freitas, J.P.X. de. 2013. Identification of passion fruit genotypes resistant to Fusarium oxysporum sp. Passiflorae. Tropical Plant Pathology 38: 236-242.

Silva, A.C., Ferreira, L.R., Silva, A.A., Ferreira, F.A. 2005a. Análise de crescimento de Brachiaria brizantha submetida a doses reduzidas de fluazifop-p-butil. Planta Daninha 23: 85-91.

Silva, F.M., Corrêa, L. de S., Boliani, A.C., Santos, P.C. dos. 2005b. Enxertia de mesa de Passiflora edulis Sims f. flavicarpa Deg. sobre Passiflora alata Curtis, em ambiente de nebulização intermitente. Revista Brasileira de Fruticultura 27: 98-101.

Vasconcellos, M.A., Silva, A.C., Silva, A.C., Reis, F.O. 2005. Ecofisiologia do maracujazeiro e implicações na exploração diversificada. In: Faleiro, F.G., Junqueira, N.T.V., Braga, M.F. Maracujá: germoplasma e melhoramento genético. Embrapa Cerrados, Planaltina, Brasil. p. 295-313. 